\title{
In vitro fracture resistance of glass-fiber and cast metal posts with different designs
}

\author{
Resistência à fratura de pinos de fibra de vidro e metálicos \\ fundidos com diferentes configurações
}

\begin{abstract}
Purpose: To evaluate the in vitro fracture resistance of roots with glass-fiber and metal dowels with different designs.

Methods: Fifty-endodontically treated maxillary central incisors were embedded in acrylic resin. Ten of them received only the coronary preparation, and the remaining forty were embedded (except for $4 \mathrm{~mm}$ of the cervical area) after removing the clinical crowns. Specimens were divided into five groups ( $n=10)$ : control (teeth with only coronary preparation), cylindrical cast dowel, conical cast dowel, cylindrical glass-fiber dowel and conical glass-fiber dowel. Specimens were subjected to an increasing compressive load $(N)$ until fracture.

Results: ANOVA indicated significant difference $(P<.05)$ among the groups, and the TukeyKramer's test identified these differences. The control group $(867 \pm 243 \mathrm{~N})$ presented the highest values and was statistically similar to cylindrical glass-fiber dowel group (711 $1180 \mathrm{~N})$. There is no significant difference among the metal dowel cylindrical $(435 \pm 245 \mathrm{~N})$ or conical $(585 \pm 164 \mathrm{~N})$ group and conical glass-fiber dowel $(453 \pm 112 \mathrm{~N})$. Cylindrical glass-fiber dowel $(711 \pm 180 \mathrm{~N})$ and conical cast dowel and core $(585 \pm 164 \mathrm{~N})$ groups had intermediate values and did not differ from each other.

Conclusions: Cylindrical glass fiber dowels represent a viable alternative to the cast-metal dowel cylindrical or conical. Cylindrical glass fiber dowels also increase endodontically treated incisors' resistance to fracture.
\end{abstract}

Key words: Fiber dowel; metallic dowel; dowel failure; resistance to fracture

\section{Resumo}

Objetivo: Avaliou-se in vitro a resistência à fratura de raízes com pinos metálicos fundidos e de fibra de vidro, variando sua configuração geométrica.

Metodologia: Cinquenta incisivos centrais superiores tratados endodonticamente foram incluídos em resina acrílica. Dez receberam apenas preparo coronário (controle) e quarenta tiveram coroas seccionadas e raízes incluídas em resina (deixando $4 \mathrm{~mm}$ cervicais). Distribuiuse os espécimes em 5 grupos: controle, pino metálico cilíndrico, metálico cônico, pino de fibra de vidro cilíndrico e cônico. Submeteram-se os corpos-de-prova a ensaio de compressão, até ocorrer a fratura.

Resultados: A ANOVA indicou diferença significante entre os grupos $(P<.05)$ e no teste de Tukey-Kramer's o controle $(867 \pm 243 \mathrm{~N})$ apresentou os maiores valores de resistência à fratura, sendo similar ao grupo do pino de fibra cilíndrico (71 1 $\pm 180 \mathrm{~N})$. Não houve diferença significante entre os pinos metálicos cilíndricos $(435 \pm 245 \mathrm{~N})$ ou cônicos $(585 \pm 164 \mathrm{~N})$ e

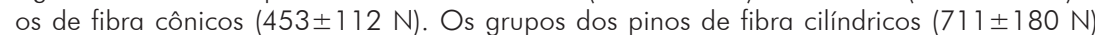
e pinos metálicos cônicos $(585 \pm 164$ N) apresentaram valores intermediários e não foram diferentes entre si.

Conclusão: Pinos de fibra de vidro são uma alternativa viável ao pino metálico fundido cilíndrico e cônico. Os pinos de fibra cilíndricos aumentaram a resistência à fratura dos incisivos tratados endodonticamente.

Palavras-chave: Pino de fibra; pino metálico; falha de pino; resistência à fratura

\author{
Fábio Henrique Pasqualin a \\ Alessandro Rogério Giovani a \\ Manoel Damião de Sousa Neto ${ }^{b}$ \\ Silvana Maria Paulinoc \\ Luiz Pascoal Vansanc
}

\begin{abstract}
- Department of Endodontics, University of Ribeirão Preto (UNAERP), Ribeirão Preto, SP, Brazil

${ }^{b}$ Department of Restorative Dentistry, University of São Paulo (FORP-USP), Ribeirão Preto, SP, Brazil

c University of Ribeirão Preto (UNAERP), Ribeirão Preto, SP, Brazil
\end{abstract}

Correspondence:
Alessandro Rogério Giovani
Rua Américo Brasiliense, apto. 601 - Centro
Ribeirão Preto, SP - Brasil
141015-050
E-mail: drgiovani@gmail.com

Received: December 21, 2011

Accepted: January 25, 2012

Conflict of Interests: The authors state that there are no financial and personal conflicts of interest that could have inappropriately influenced their work.

Copyright: (C) 2011 Pasqualin et al. licensee EDIPUCRS. This is an Open Access article distributed under the terms of the Creative Commons AttributionNoncommercial-No Derivative Works 3.0 Unported License. 


\section{Introduction}

Endodontically treated teeth, with extensive loss of coronal tooth structure, are commonly restored with a dowel, core, and crown. The choice of the dowel is dependent of the internal configuration and morphology of the root (1) the principles of the dowel retention such as the diameter, surface, geometrical configuration (1-3) and the different types of materials used to fabricate these systems and their mechanical properties (4).

Cast metal dowels and core have been used for many years. This technique however is time-consuming and needs a greater number of sessions and laboratory procedures. Dowels and cores often need adjustment to achieve an adequate fit, are expensive, and require a greater removal of the remaining healthy dental tissue (5-6). Furthermore, their metal color and the pigmentation of the dentin structure, due to the oxidation process, transfer coloration to the root and gum (which differs from the natural color) (7).

Recently, glass-fiber dowels have been used as a viable alternative to treatments in which aesthetic is involved. A prefabricated dowel can be classified according to their geometrical configuration (conical and cylindrical dowels), in relation to their form of retention (active and passive dowels), and to their structural composition (metal, ceramic, or resin reinforced with fibers). Prefabricated dowels are reported to be more flexible than cast metal dowels and allow a better distribution of forces (resulting in fewer root fractures) $(2,8)$. These prefabricated dowels are advantageous in situations in which adequate coronal tooth structure remains (9-10).

Dowel and the crown failures can result in the fracture of the dowel and root, and the displacement of the dowel. One of the most frequent causes of failure is the fracture of the remaining tooth structure (11-13). Previous studies have suggested that the susceptibility of teeth (restored with dowels) to fracture may be related to the quantity of the remaining crown and the radicular structure. Other factors leading to fracture involve the dowel's composition such as the modulus of elasticity, diameter, length, and geometrical configuration (11-18).

In some studies, researchers have found that the fracture of teeth (with dowels) is related to the dowel's geometrical configuration. For example, conical dowels have a lower retention and wedge effect that generates internal stress during function. This internal stress may cause root fracture. Conical dowels, however, require minimal removal of the dental structure and allow a better adaptation of the root canal due to the similarity to its anatomical conformation (17-19). Cylindrical dowels have greater retention than conical dowels. These dowels require a larger removal of the dental structure but offer a lower risk of fracture (because they more evenly distribute the stress along the root canal) (17-19).

In research studies that investigate compressive and tensile forces on teeth (with various dowel designs), the load has been applied mainly to the dowel or core structure. In clinical practice, a crown covers the patient's dowel and core. Under such circumstances, photoelastic and mechanical studies have reported no significant difference between tapered and cylindrical dowels. If the tooth is covered by a complete crown, the type of dowel may slightly impact the risk for root fracture (with a good ferrule effect at the crown margin area) $(8,20-24)$.

The purpose of this in vitro study was to evaluate the fracture resistance of roots with cast dowels, and cores and glass-fiber dowels of different designs (by using a compressive test). Our null hypothesis was that we would find no difference in the fracture resistance of endodontically treated central incisors. These incisors were restored with different types of dowel systems (of different designs).

\section{Material and methods}

The Ethics Committee in Research at the University of Ribeirao Preto (UNAERP) approved this study's research.

Fifty-caries-free and restoration-free- human-maxillarycentral incisors with roots of similar form were selected. All these teeth had a single canal and straight roots measuring approximately $16 \mathrm{~mm}$. The clinical crowns of 40 teeth were sectioned transversally, close to the cement-enamel junction, leaving a root length of $13 \mathrm{~mm}$. The remaining ten teeth stayed intact.

The 40 root canals were initially explored by introducing a \#35 K file number (Dentsply-Maillefer, Ballaigues, Switzerland), and selected the specimens that had a working length of $12 \mathrm{~mm}$ and an anatomical diameter of $350 \mu \mathrm{m}$. The preparation of the radicular canal was accomplished with Gates-Glidden drills (Dentsply-Maillefer, Ballaigues, Switzerland) \#2 and \#3. The biomechanical preparation (crown-down technique) of the root canal was carried out using the manual K files (Dentsply-Maillefer, Ballaigues, Switzerland), and (up to) a number 55 master apical file was standardized for all specimens. During preparation, the canals were irrigated with $2 \mathrm{~mL}$ of $1 \%$ sodium hypochlorite, alternating with $17 \%$ ethylenediaminetetraacetic acid (EDTA). Final irrigation was performed with $10 \mathrm{~mL}$ of distilled water, and the canals were dried with absorbent paper points (Dentsply, Petrópolis, RJ, Brazil). Root canals were obturated with master and accessory gutta-percha cones (Tanari, Manacapuru, AM, Brazil) and sealer (Sealer 26, Dentsply, Petrópolis, RJ, Brazil), using the lateral condensation technique. The excess of gutta-percha was removed by using heated condensers (Duflex, SS White, Rio de Janeiro, RJ, Brazil). Vertical condensation was performed with the same instruments, and the pulpal chambers were sealed with provisional cement (Citodur, DoriDent, Vienna, Austria). Specimens were immersed in distilled water and maintained at $37^{\circ} \mathrm{C}\left( \pm 2{ }^{\circ} \mathrm{C}\right)$ for 36 hours.

The roots were placed in aluminum molds $(16 \times 16 \times$ $32 \mathrm{~mm}$ ) and embedded in acrylic resin (Jet-Clássico, São Paulo, SP, Brazil) to maintain $4 \mathrm{~mm}$ of root length. This root length was extended beyond the top of the acrylic resin. For the cervical preparation of the roots, a reference line 
was marked at a height of $2 \mathrm{~mm}$. A diamond rotary cutting instrument (3069 diamond bur, KG-Sorensen, São Paulo, SP, Brazil) was used to prepare orientation notches with a depth of $1 \mathrm{~mm}$. From these notches, the cervical portion of the tooth was prepared, resulting in a cervical terminus with a square shoulder.

The ten teeth without endodontic treatment (whose crowns were not clinically removed) were embedded in the same way as the other specimens and constituted the Control Group (group C). The remaining specimens were divided into two groups $(\mathrm{n}=20)$ according to their dowel designs: group cylindrical (Cy) and group conical (Co). Each group was then divided into two subgroups according to the dowel material $(n=10)$ : cast dowel and core $(C D C)$ or glass-fiber dowel (GFD). Dowel spaces were prepared with parallelsided burs from the dowel kit FiberKleer Parallel Post (Pentron Clinical Technologies, Wallingford, Connecticut) for cylindrical group. Dowel spaces were prepared with a FiberKleer Tapered Post (Pentron Corporation, Wallingford, USA) for conical group, and with a low-speed handpiece (Dabi Atlante SA, Ribeirão Preto, Brazil) attached to a dental surveyor (Bio-Art, São Carlos, Brazil).

The teeth of the control group (group C) were not submitted to endodontic treatment and did not have the crowns removed. This control group received coronary preparation with \#3069 diamond bur (KG-Sorensen, São Paulo, SP, Brazil). The coronary preparation was standardized as $5 \mathrm{~mm}$ in height and $1 \mathrm{~mm}$ in width.

A mold in the anatomical form of a core and in the complete crown of the maxillary central tooth was used to standardize the coronal portion of the core. This anatomical form was cast in copper-aluminum alloy (Goldent, AJE Goldent Comercial Ltda, São Paulo, Brazil). With this standard mold, we were able to obtain 40 -acetate molds with a plastifier (Bio-Art) under vacuum. These molds were used to help us fabricate the wax patterns (in the coronal portion of the core).

In the groups $\mathrm{CyCDC}$ and $\mathrm{CoCDC}$, the dowels were created by using the direct technique with acrylic resin (DuraLay, Reliance Dental Manufacturing Co, Worth, Illinois) and prefabricated dowels (Pin-Jet posts, Angelus Dental Solutions, Londrina, Brazil). The prepared dowel spaces were lubricated with petroleum jelly (União Química F TCA Nacional SA, São Paulo, Brazil) and the acrylic resin was placed into the prepared dowel space using the \#40 Lentulo bur (Dentsply Maillefer). Next, the prefabricated plastic dowel was inserted. The acetate mold was filled with acrylic resin (DuraLay, Reliance Dental Manufacturing Company) and placed on the dowel pattern. Any necessary finishing was performed with a diamond rotary cutting instrument (3069 diamond bur, KG Sorensen). The acrylic resin patterns were invested in a phosphate-bondedinvestment material (Termocast, Polidental, Polidental, São Paulo, Brazil) and cast in copper-aluminum alloy (Goldent, AJE Goldent Comercial Ltda). The castings were airborneparticle abraded with a $150-\mu \mathrm{m}$ aluminum-oxide powder (Wilson, Polidental).
Cast dowels were cemented with dual-cure-resin cement (Panavia F, Kuraray Co Ltd, Osaka, Japan) and an adhesive system (Kuraray Co Ltd). Primer (Alloy Primer; Kuraray Co Ltd) was applied to the post. Then, each canal surface was acid etched (Ivoclar Vivadent, São Paulo, Brazil) for 30 seconds, rinsed with water, and dried with paper points (Dentsply). Two coats of adhesive were applied, followed by 20 seconds of drying and light-activated with a halogen lamp (Ultralux Electronic, Dabi Atlante SA) for 30 seconds. The unit had a wavelength of 350 to $500 \mathrm{~nm}$ and light intensity of 350 to $500 \mathrm{~mW} / \mathrm{cm} 2$. The light was positioned perpendicular to the long axis of the root, and the distance of the light tip from the specimens was $2.0 \mathrm{~mm}$. The cement (Panavia F, Kuraray Co Ltd) was applied in accordance with the manufacturer's instructions. A Lentulo spiral instrument (Dentsply Maillefer) was used for the application of the cement inside the prepared canals. The premature polymerization of the resin cement (in the canal) was avoided by inserting the dowel immediately after the placement of the cement. Any excess cement was removed, and the core was maintained under constant finger pressure for 60 seconds. The resin-cement was light-activated (Ultralux Eletronic, Dabi Atlante SA) for 60 seconds. A sixminute waiting period allowed complete polymerization of the cement. An oxygen barrier (Oxyguard II gel, Kuraray Co Ltd) was applied to the superficial margins for ten minutes and then removed with cotton rolls and water spray.

The glass-fiber dowels were cemented with Panavia F cement (Kuraray Co Ltd) to obtain groups CyGFD and COGFD. For this, the same protocol used for groups CDC, with the exception of the primer application procedure, was followed. To fabricate the core, the tooth structure was conditioned with $37 \%$ phosphoric acid gel (Ivoclar Vivadent) for 15 seconds, washed under a water stream for 20 seconds, and dried with compressed air. In sequence with the dentin wet, two coats of the adhesive (Prime and Bond 2.1, Dentsply) were applied, with an interval of 30 seconds between coats to allow the solvent evaporation. Compressed air was applied for five seconds, and light-activation was performed for 20 seconds. Layers of composite resin (Z100, 3M ESPE, Saint Paul, Minn) were applied successively around the prefabricated dowel, and each layer (approximately $0.5 \mathrm{~mm}$ thick) was light-activated for 20 seconds. To obtain the core form, the acetate molds were filled with composite resin and positioned above the coronal portions. The excess composite resin was removed and the core was light-activated for 40 seconds. After polymerization, the acetate molds were removed.

During the compressive test, metal crowns were made for all the specimens (for the standardization of applied force during the compressive test). The specimens were prepared by placing a chamfer at the cervical shoulder with a diamond rotary cutting instrument (\#4219, KG Sorensen). A fine coat of petroleum jelly (União Química, F TCA Nacional SA) was applied to the coronal portion of the core. The crown patterns were made with casting wax (Odontofix, Ribeirão Preto, Brazil), invested in a phosphate-bonded-investment 
material (Termocast, Polidental), and cast in Co-Cr alloy (Resilient Plus, Metalúrgica Riosulense SA, Santa Catarina, Brazil) according to the manufacturer's instructions. The crowns were airborne-particle abraded with a $150-\mu \mathrm{m}$ aluminum-oxide powder (Wilson, Polidental).

All crowns were cemented with zinc phosphate cement (Zinc Cement, SS White) in a ratio of $2.0 \mathrm{~g}$ of phosphate zinc powder to $0.5 \mathrm{~mL}$ of liquid. The crowns were filled with cement, placed on the preparations, and then constant finger pressure was applied for 60 seconds. After ten minutes, the excess cement was removed with a dental explorer. The specimens were stored in $100 \%$ relative humidity, at a constant temperature of $37^{\circ} \mathrm{C}\left( \pm 2^{\circ} \mathrm{C}\right)$, for a period of 72 hours.

The specimens were subjected to a compressive test in a universal testing machine (Instron 4444, Instron Corp, Norwood, Mass). A device was used to standardize the position of the specimens at the base of the apparatus. At this position, the load could be applied at an angle of 135 degrees in relation to the long axis of the roots. An increasing oblique compressive load was applied on the cingulum of the palatal surface ( $3.0 \mathrm{~mm}$ from the incisor region) by using a cylindrical-shaped device with a round terminus $(2.7 \mathrm{~mm}$ in diameter). A crosshead speed of one $\mathrm{mm} / \mathrm{min}$ was applied until the root fractured.

The values (of the forces required for the roots to fracture) obtained in $\mathrm{N}$ were submitted to preliminary-statisticaltests-using software (InStat, GraphPad Software, Inc, La Jolla, California) to verify the normality of the distribution. One-way ANOVA parametric statistical test $(\alpha=.05)$ and the Tukey-Kramer's test $(\alpha=.05)$ were used to analyze the data.

\section{Results}

The mean values of the compressive loads (required to fracture roots) for each of the five groups are displayed in Table 1. ANOVA indicated significant differences $(P<.05)$ among the groups (Table 2). The Tukey-Kramer's test showed no statistical differences among the metal dowel conical or cylindrical groups (Table 3 ). The control group differed from the following experimental groups: cylindrical cast dowels $(P<.001)$, conical cast dowels $(P<.05)$, and conical glass-fiber dowels $(P<.001)$. The type and location of fractures were evaluated. The percentage values are listed in Table 4.

\section{Discussion}

In this study, the fracture resistance of roots that were submitted to endodontic treatment and restored with cast metal and glass-fiber dowels (with different designs) was evaluated. The null hypothesis was that there would be no difference in the fracture of endodontically treated teeth restored with different types of dowel systems and designs. The present results reject this null hypothesis.

In order to preserve the maximum dental structure, we specifically used teeth, which had been submitted to coronary preparation without endodontic treatment, as the control group. According to $\mathrm{Ng}$ et al. (12) and Mezzomo et al. (16) teeth with less tissue damage have a greater resistance to fracture. The dowel space of the root was prepared using the standards recommended by Shillingburg et al. (22) which stated that the prosthetic preparation must be two-thirds of the tooth length.

Table 1. Mean values* (SD) of compressive strength $(\mathrm{N})$ required for root fracture.

\begin{tabular}{|c|c|c|c|c|}
\hline Control Group & CyCDC & CoCDC & CyGFD & CoGFD \\
\hline $867 \mathrm{~N} \pm 243^{a}$ & $435 \mathrm{~N} \pm 245^{b}$ & $585 \mathrm{~N} \pm 164 \mathrm{bc}$ & $711 \mathrm{~N} \pm 180^{\circ \mathrm{c}}$ & $453 \mathrm{~N} \pm 112^{b}$ \\
\hline
\end{tabular}

Table 2. One-way ANOVA.

\begin{tabular}{lccccc}
\hline $\begin{array}{l}\text { Source of } \\
\text { variation }\end{array}$ & SS. & df & Ms & F & $P$ \\
\hline Between groups & 1321490 & 4 & 330373 & 8839 & 0.1970 \\
Residual & 1682006 & 45 & 37378 & & \\
Total & 0.0107 & 49 & & & \\
\hline
\end{tabular}

Table 3. Tukey-Kramer's test, between groups.

\begin{tabular}{lc}
\hline \multicolumn{1}{c}{ Types of post } & Means* \\
\hline Control group & $867^{\mathrm{a}}$ \\
Cylindrical cast dowel and core & $435^{\mathrm{b}}$ \\
Conical cast dowel and core & $585^{\mathrm{bc}}$ \\
Cylindrical glass-fiber dowel & $711^{\mathrm{ac}}$ \\
Conical glass-fiber dowel & $453^{\mathrm{b}}$ \\
\hline
\end{tabular}

* Groups with same superscript letter were not significantly different according to Tukey-Kramer's test $(P>.05)$.
Table 4. Percentage of fractures in relation to location of root fracture according to dowel type.

\begin{tabular}{lcccc}
\hline \multirow{2}{*}{ Place of the fracture } & \multicolumn{4}{c}{ Dowel type } \\
\cline { 2 - 5 } & \multicolumn{2}{c}{ Cast metal } & \multicolumn{2}{c}{ Glass fiber } \\
\cline { 2 - 5 } & Cylindrical & Conical & Cylindrical & Conical \\
\hline Cervical & 90.0 & 20.0 & 100 & 40.0 \\
Middle & 10.0 & 80.0 & 0 & 60.0 \\
Apical & 0 & 00.0 & 0 & 0 \\
\hline
\end{tabular}


In relation to the variation of the geometrical configuration of the cast metal dowels, the results showed that the dowel form (cylindrical or conical) did not influence the fracture resistance of the roots. The authors hypothesize that, regardless of the design, when a rigid cast dowel with a high modulus of elasticity is submitted to stress or an oblique compressive load the rigid cast dowel does not absorb energy. Rather, the rigid cast dowel transmits energy to a less rigid structure. In this case, the rigid cast dowel transmitted energy to the dentin. The dentin has a lower modulus of elasticity and increases the fracture potential of the root $(3,11)$.

Hayashi et al. (11) noted that a tooth's (restored with cast dowels) susceptibility to fracture is related to the dowel's stiffness. With respect to the glass-fiber dowels, the results indicated that the geometrical configuration of the dowels influenced the susceptibility to root fracture. Dowels, with a modulus of elasticity similar to dentin (such as the glassfiber dowel), can better absorb the forces concentrated along the root when submitted to a compressive load. The dowels ability to absorb the concentrated forces may decrease the probability of fracture $(8,23)$.

The roots restored with cylindrical dowels had a behavior similar to the control group, and the lowest susceptibility to fracture (than the conical dowels). The cylindrical dowels have a greater capacity to absorb stress (since they have a greater mass volume (4) when submitted to a compressive load. The cylindrical dowels do not transfer stress to the dentin $(14,17)$. In contrast the conical dowel, due to its geometrical configuration, absorbs a lesser amount of stress and can generate a wedge effect (17). This phenomenon may explain the results obtained in this study for the CyGFD group. This group (given their larger mass volume) possessed the capacity to absorb a greater amount of stress, rather than transferring this stress to the dentin. However, CoGFD dowels appeared to concentrate stress in the smaller area of radicular dentin, creating a greater susceptibility to fracture (24).

All the specimens were restored with dowels $10 \mathrm{~mm}$ long (in correspondence to two-thirds of the root). According to the recommendation of Shillingburg et al. (22), the dowel restoration allows the dissipation of forces over a greater area of the root dentine (17). Thus, although the compressive force was the same for all groups, the place of fracture may have been different. According to Hayashi et al. (11) and Giovani et al. (24), cast metal dowels fractures are predominantly in the apical region, due to the transfer of the oblique compressive load of the dowel to the dentin. According to Fokkinga et al. (14), Hayashi et al. (11) and Giovani et al. (24) this fracture location makes a new root restoration impossible.

This current study has the following limitations. The type of testing used, a single cycle to failure, does not represent the intraoral condition. Intraorally, teeth are subjected to cyclic loading through mastication and are immersed in a wet environment that is subject to chemical and thermal changes. The study evaluated maxillary central incisors, and the results can only be applied to that group of teeth. Furthermore, cement pressure was not standardized as only finger pressure was used.

Glass-fiber dowels appear to be a good alternative to the cast metal dowels due to the satisfactory biomechanical properties, good esthetics, and reduction in costs $(2,3,18,20,25)$. We believe further research is required to evaluate the behavior of the different dowel systems and their respective properties, providing dentists with the means to effectively solve each clinical case.

\section{Conclusions}

Within the limitations of this in vitro study, the following conclusions were drawn:

The pre-fabricated cylindrical glass-fiber dowels have a higher value of fracture resistance with values similar to the specimens of the control group $(P>.05)$.

The cylindrical and conical cast metal dowels and the conical glass-fiber dowels did not differ significantly in terms of the compressive load required to fracture the root (showing the lowest values for resistance to compression than the control group).

\section{Acknowledgment}

This study was financially supported by the Brazilian agency CAPES (Coordination for Improvement of Higher Education Personnel), grant number PROSUP 0012/02-5.
References

son JK, Sakumura JS. Dowel form and tensile force. J Prosthet Dent 1978;40:645-9.

2. Silva NR, Castro CG, Santos-Filho PC, Silva GR, Campos RE, Soares PV et al. Influence of different post design and composition on stress distribution in maxillary central incisor: finite element analysis. Indian J Dent Res 2009;20:153-8.

3. Chuang SF, Yaman P, Herrero A, Dennison JB, Chang CH. Influence of post material and length on endodontically treated incisors: an in vitro and finite element study. J Prosthet Dent 2010;104:379-88.

4. Deutsch AS, Musikant BL, Cavallari J, Silverstein L, Lepley J, Ohlen K et al. Root fracture during insertion of prefabricated posts related to root size. J Prosthet Dent 1985;53:786-9.

5. Schwartz RS, Robbins JW. Post placement and restoration of endodontically treated teeth a literature review. J Endod 2004;30:289-301. 
6. Hatta M, Shinya A, Vallittu PK, Shinya A, Lassila LV. High volume individual fiber post versus low volume fiber post: the fracture load of the restored tooth. J Dent $2011 ; 39: 65-71$.

7. Purton DG, Chandler NP, Qualtrough AJ. Effect of thermocycling on the retention of glassfiber root canal post. Quintessence Int 2003;34:366-9.

8. Freedman GA. Esthetic post-and-core treatment. Dent Clin North Am 2001;45:103-16.

9. Iglesia-Puig MA, Arellano-Cabornero A. Fiber-reinforced post and core adapted to a previous metal ceramic crown. J Prosthet Dent 2004;91:191-4.

10. Narva KK, Lassila LV, Vallittu PK. Fatigue resistance and stiffness of glass fiber-reinforced urethane dimethacrylate composite. J Prosthet Dent 2004;91:158-63.

11. Hayashi M, Takahashi Y, Imazato S, Ebisu S. Fracture resistance of pulpless teeth restored with post-cores and crowns. Dent Mater 2006;22:477-85.

12. Ng CC, Dumbrigue HB, Al-Bayat Ml, Griggs JA, Wakefield CW. Influence of remaining coronal tooth structure location on the fracture resistance of restored endodontically treated anterior teeth. J Prosthet Dent 2006;95:290-6.

13. Al-Wahadni AM, Hamdan S, Al-Omiri M, Hammad MM, Hatamleh MM. Fracture resistance of teeth restored with different post systems: in vitro study. Oral Surg Oral Med Oral Pathol Oral Radiol Endod 2008;106:77-83.

14. Fokkinga WA, Kreulen CM, Le Bell-Rönnlöf AM, Lassila LV, Vallittu PK, Creugers NH. In vitro fracture behavior of maxillary premolars with metal crowns and several post-and-core systems. Eur J Oral Sci 2006; 1 14:250-6.

15. Grieznis L, Apse P, Soboleva U. The effect of 2 different diameter cast posts on tooth root fracture resistance in vitro. Stomatologija 2006;8:30-2.

16. Mezzomo E, Massa F, Suzuki RM. Fracture resistance of teeth restored with 2 different postand-core designs fixed with 2 different luting cements: an in vitro study. Part II. Quintessence Int 2006;37:477-84.

17. Teixeira EC, Teixeira FB, Piasick JR, Thompson JY. An in vitro assessment of prefabricated fiber post system. J Am Dent Assoc 2006;137:1006-12.

18. Seefeld F, Wenz HJ, Ludwig K, Kern M. Resistance to fracture and structural characteristics of different fiber reinforced post systems. Dent Mater 2007;23:265-71.

19. Schwartz RS, Robbins JW. Post placement and restoration of endodontically treated teeth: a literature review. J Endod 2004;30:289-301.

20. Qing H, Zhu Z, Chao Y, Zhang W. In vitro evaluation of the fracture resistance of anterior endodontically treated teeth restored with glass fiber and zircon posts. J Prosthet Dent 2007;97:93-8.

21. Martinez-Insua A, Da Silva L, Rilo B, Santana U. Comparison of the fracture resistances of pulpless teeth restored with a cast post and core or carbon-fiber post with a composite core. J Prosthet Dent 1998;80:527-32.

22. Shillingburg HT Jr, Fisher DW, Dewhirst RB. Restoration of endodontically treated posterior teeth. J Prosthet Dent 1970;24:401-9.

23. Standlee JP, Caputo AA, Collard EW, Pollack MH. Analysis of stress distribution by endodontic posts. Oral Surg Oral Med Oral Pathol 1972;33:952-60.

24. Giovani AR, Vansan LP, De Sousa Neto MD, Paulino SM. Dent In vitro fracture resistance of glass-fiber and cast metal posts with different lengths. J Prosthet Dent 2009;101:183-8.

25. Manhart J. Fabricating fiber-reinforced composite posts. Dent Today $2011 ; 30: 84,86,88-92$. 